\title{
EVALUASI INSTALASI LISTRIK PADA GEDUNG MULTI CENTRE OF EXCELLENT (MCE) RUMAH SAKIT ISLAM SULTAN AGUNG SEMARANG
}

\author{
Eko Wahyu Pramono ${ }^{[1]}$, Karnoto $^{[2]}$, Titik Nurhayati ${ }^{[2]}$. \\ ${ }^{1,2,3}$ Teknik Elektro Universitas Semarang \\ Email : ekowahyupramono@yahoo.com
}

\begin{abstract}
Abstrak - Gedung MCE Rumah Sakit Islam Sultan Agung Semarang merupakan fasilitas umum sehingga diperlukan sistem instalasi listrik yang sesuai dengan PUIL 2000. Tujuan evaluasi instalasi listrik pada gedung Multi Centre of Excellent (MCE) Rumah Sakit Islam Sultan Agung Semarang yaitu untuk mengetahui instalasi listrik sesuai dengan PUIL 2000. Evaluasi instalasi listrik meliputi perhitungan pengaman MCB dan perhitungan ukuran kabel. Perhitungan menggunakan metode perhitungan manual dan perhitungan menggunakan software Ecodial Calculation 4.7. Hasil perhitungan kemudian dibandingkan dengan unit terpasang. Dari hasil perbandingan dapat diketahui apakah instalasi listrik sudah sesuai dengan PUIL 2000.

Hasil analisa dapat disimpulkan bahwa sistem instalasi listrik pada gedung MCE Rumah Sakit Islam Sultan Agung Semarang dalam keadaan baik dan aman. Pada unit terpasang pengaman MCB sudah sesuai dengan standar PUIL 2000. Pada ukuran kabel yang terpasang beberapa dalam kondisi tidak sesuai dengan standar PUIL 2000 sehingga diperlukan penggantian kabel. Contohnya pada kabel SDP 1 Panel Pembagi Lantai 1 dimana kabel yang terpasang adalah 4x35 mm2 diganti menjadi 4x95 mm2.

Kata kunci : Evaluasi Instalasi Listrik, PUIL 2000, Ecodial Advance
\end{abstract} Calculation 4.7.

Abstract : MCE Building Sultan Agung Islamic Hospital Semarang is a public facility that requires an electrical installation system that is in accordance with PUIL 2000. The purpose of evaluating electrical installations at the Multi Center of Excellent (MCE) building in Sultan Agung Semarang Islamic Hospital is to find out electrical installations in accordance with PUIL 2000 Evaluation of electrical installations includes calculation of MCB security and calculation of cable size. Calculation using manual calculation method and calculation using Ecodial Calculation 4.7 software. The calculation results are then compared to the installed units. From the results of the comparison it can be seen whether the electrical installation is in accordance with PUIL 2000.

The results of the analysis can be concluded that the electrical installation system in the MCE building of Sultan Agung Semarang Islamic Hospital is in good condition and safe. In MCB installed units, they are in accordance with the PUIL 2000 standard. In the cable sizes installed several are in a condition not in accordance with the PUIL 2000 standard so cable replacement is required. For example, on the 1st floor divider panel SDP cable where the installed cable is $4 \times 35 \mathrm{~mm} 2$, it is replaced by $4 \times 95 \mathrm{~mm} 2$.

Keywords: Evaluation of Electrical Installation, PUIL 2000, Ecodial Advance Calculation 4.

\section{PENDAHULUAN}

Instalasi listrik adalah saluran beserta gawai maupun peralatan yang terpasang baik di dalam maupun di luar bangunan untuk menyatukan arus listrik. Instalasi listrik merupakan bagian penting dari sebuah bangunan gedung. Instalasi listrik berfungsi sebagai penunjang kenyamanan penghuninya. Bangunan gedung bertingkat membutuhkan sistem instalasi listrik yang handal untuk memenuhi kebutuhan energy listrik di setiap ruang dalam gedung tersebut. Rancangan instalasi listrik harus memenuhi ketentuan sesuai Persyaratan Umum Instalasi Listrik (PUIL) dan peraturan lainnya seperti ; undang - undang Nomor 1 Tahun 1970 tentang keselamatan kerja beserta peraturan pelaksanaannya, undang - undang Nomor 23 Tahun 1997 tentang Pengelolaan Lingkungan Hidup, undang - undang Nomor 30 Tahun 2009 tentang Ketenagalistrikan.

Perancangan sistem instalasi listrik harus memperhatikan tentang keselamatan manusia, makhluk hidup lain dan keamanan harta benda dari bahaya dan kerusakan yang bisa ditimbulkan oleh penggunaan instalasi listrik. Selain itu, berfungsinya instalasi listrik harus dalam keadaan baik dan sesuai dengan maksud penggunaannya.

\section{TINJAUAN PUSTAKA}

Rumah sakit merupakan sarana umum yang berfungsi merawat pasien dengan baik. Instalasi listrik rumah sakit mempunyai keunikan tersendiri dibanding gedung - gedung lain. Keunikan ini disebabkan dengan kelangsungan hidup manusia. Instalasi listrik setiap ruangan rumah sakit yang berhubungan dengan pasien harus didesain dengan baik.

Gedung rumah sakit harus memenuhi syarat - syarat listrik sebagai berikut :

a. Kontinyunitas suplai daya

Kontinyunitas suplai daya dapat terpenuhi apabila aliran listrik yang menuju beban selalu terpenuhi. Agar kontinyunitas suplai daya selalu terpenuhi, maka harus disediakan suplai listrik cadangan ketika suplai daya utama terganggu. Suplai daya cadangan berupa generator set.

b. Keamanan instalasi listrik

Pengaman terhadap gangguan listrik sangat diperlukan karena menyangkut keselamatan orang banyak di dalam rumah sakit.

c. Besaran - besaran listrik sesuai dengan standar

Besaran - besaran listrik yaitu tegangan, arus, frekuensi, sistem pengaman, dan sistem pentanahan harus 
diperhatikan karena menentukan baik tidaknya sistem instalasi listrik.

Sistem instalasi listrik dibagi menjadi instalasi penerangan dan instalasi daya listrik. Instalasi penerangan adalah seluruh instalasi listrik yang digunakan untuk memberikan daya listrik pada lampu atau peralatan listrik lainnya. Instalasi penerangan dibagi menjadi instalasi dalam gedung dan instalasi luar gedung. Sedangkan instalasi daya listrik adalah suatu jaringan atau rangkaian untuk menyuplai dan menyalurkan daya listrik dari sumber menuju beban. Instalasi daya listrik terdiri dari beberapa bagian yaitu ; penyedia tenaga listrik, sistem pembagian daya listrik (grouping), saluran daya listrik, pengaman dan pentanahan (grounding)

Prinsip dasar instalasi listrik harus mempertimbangkan pemasangan suatu instalasi listrik agar instalasi yang dipasang dapat digunakan secara optimal, efektif dan efisien.

Prinsip dasar instalasi listrik yaitu sebagai berikut :

a. Keandalan

Seluruh peralatan yang dipakai pada instalasi harus handal dan baik secara mekanik maupun secara kelistrikan.

b. Ketercapaian

Pemasangan peralatan instalasi listrik yang relatif mudah dijangkau oleh pengguna pada saat mengoperasikannya dan tata letak komponen listrik mudah untuk dioperasikan, sebagai contoh pemasangan sakelar tidak terlalu tinggi atau terlalu rendah.

c. Ketersediaan

Ketersediaan instalasi listrik dalam melayani kebutuhan baik berupa daya, peralatan maupun kemungkinan perluasan instalasi. Apabila ada perluasan instalasi tidak mengganggu sistem instalasi yang sudah ada, tetapi hanya menghubungkan pada sumber cadangan (spare) yang telah diberi pengaman.

d. Keindahan

Pemasangan peralatan instalasi listrik haus dipasang sedemikian rupa, sehingga terlihat rapi dan indah serta tidak menyalahi peraturan yang berlaku.

e. Keamanan

Faktor keamanan dari suatu instalasi listrik, baik keamanan terhadap manusia, bangunan atau harta benda, makhluk hidup lain dan peralatan itu sendiri.

f. Ekonomis

Biaya yang dikeluarkan dalam pemasangan instalasi listrik harus diperhitungkan dengan teliti dengan biaya sehemat mungkin.

Salah satu faktor teknis yang perlu diperhatikan dalam penyediaan dan penyaluran daya listrik adalah kualitas daya. Faktor ini meliputi stabilitas tegangan, kontinyunitas pelayanan, keandalan pengamanan dan kapasitas daya yang sesuai kebutuhan. Pengaman adalah suatu peralatan listrik yang digunakan untuk melidungi komponen listrik dari kerusakan yang diakibatkan oleh gangguan seperti arus beban lebih ataupun arus hubung singkat. Pengaman yang baik adalah pengaman yang langsung merespon atau trip ketika terjadi gangguan. Jenis gangguan yang paling sering terjadi dalam keadaan sistem berjalan normal adalah gangguan arus lebih atau biasa disebut beban lebih. Jenis gangguan lain yang juga sering terjadi adalah gangguan arus hubung singkat atau short circuit.

Ecodial Advance Calculation INT 4.7 adalah program perhitungan yang dimiliki oleh Schneider Electric yang berguna untuk mendesain instalasi listrik tegangan rendah pada suatu jaringan instalasi listrik di sektor bangunan gedung. Program Ecodial Advance Calculation INT 4.7 menggunakan standar internasional yaitu IEC60364.

\section{* Keuntungan}

a) Alat referensi untuk instalasi listrik yang handal

b) Menghemat waktu perhitungan

c) Instalasi listrik sesuai standar yang berlaku

Rumus kemampuan hantar arus (KHA) sebagai berikut :

Beban 3 fasa :

In $=P /\left(\sqrt{3} \times V_{L-L} \times \cos \theta\right)$

Keterangan :

In = Arus Nominal (A)

$P=$ Daya beban $(\mathrm{W})$

$V=$ Tegangan kerja $(\mathrm{V})$

$\operatorname{Cos} \varphi=$ Faktor daya sistem

Kabel penghantar merupakan komponen yang sangat penting karena merupakan konduktor yang menghantarkan arus listrik.

KHA mempunyai nilai aktual $100 \%$ bila kabel tersebut dipasang pada temperatur kelilingnya maksimal $30{ }^{\circ} \mathrm{C}$. Namun jika lebih dari suhu tersebut akan terjadi penurunan nilai aktual KHA. Dalam PUIL penurunan nilai ini diatur dalam faktor koreksi.

Tabel 1. KHA terus menerus untuk kabel instalasi berinti tunggal berisolasi PVC pada suhu keliling $30^{\circ} \mathrm{C}$ [PUIL 2000, hal. 304]

\begin{tabular}{|c|c|c|c|}
\hline \multirow{3}{*}{ Jenis kabel } & \multirow{2}{*}{$\begin{array}{c}\text { Kabel } \\
\mathbf{m m}^{2}\end{array}$} & \multicolumn{2}{|c|}{ KHA } \\
\cline { 2 - 4 } & & \multicolumn{2}{|c|}{ Berinti tunggal } \\
\cline { 2 - 4 } & 2 & 3 & 4 \\
\hline Nanah (A) & Udara(A) \\
\hline NYY & 1,5 & 40 & 26 \\
\cline { 2 - 4 } NYBY & 2,5 & 54 & 35 \\
\cline { 2 - 4 } NYFGbY & 4 & 70 & 46 \\
\cline { 2 - 4 } NYRGbY & 6 & 90 & 58 \\
\cline { 2 - 4 } NYCY & 10 & 122 & 79 \\
\cline { 2 - 4 } NYCWY & 16 & 160 & 105 \\
NYSY & 25 & 206 & 140 \\
\cline { 2 - 4 } NYCEY & 35 & 249 & 174 \\
\cline { 2 - 4 } NYSEY & 50 & 296 & 212 \\
\cline { 2 - 4 } NYHSY & 70 & 365 & 269 \\
\cline { 2 - 4 } NYKY & 95 & 438 & 331 \\
\cline { 2 - 4 } NYKBY & 120 & 499 & 386 \\
\cline { 2 - 4 } NYKFGBY & 150 & 561 & 442 \\
\cline { 2 - 4 } NYKRGbY & 185 & 637 & 511 \\
\cline { 2 - 4 } & 240 & 743 & 612 \\
\cline { 2 - 4 } & 300 & 843 & 707 \\
\cline { 2 - 4 } & 400 & 986 & 859 \\
\cline { 2 - 4 } & 500 & 1125 & 1000 \\
\hline
\end{tabular}


Tabel 2. Faktor Koreksi untuk KHA terus menerus untuk kabel instalasi berinti tunggal berisolasi PVC pada suhu keliling $30{ }^{\circ} \mathrm{C}$ dan suhu penghantar maksimum $70{ }^{\circ} \mathrm{C}$ [ PUIL 2000 hal. 302 ]

\begin{tabular}{|c|c|c|}
\hline \multirow{2}{*}{ Suhu keliling } & \\
& & \multicolumn{2}{|c|}{$\mathbf{C}$} & Fartor & Koreksi \\
\cline { 2 - 3 } & 2 & 3 \\
\hline 1 & 0,98 & 1,00 \\
\hline $\mathrm{t}<30^{\circ} \mathrm{C}$ & 0,90 & 0,94 \\
\hline $30^{\circ} \mathrm{C}<\mathrm{t}<35^{\circ} \mathrm{C}$ & 0,80 & 0,87 \\
\hline $35^{\circ} \mathrm{C}<\mathrm{t}<40^{\circ} \mathrm{C}$ & 0,69 & 0,80 \\
\hline $40^{\circ} \mathrm{C}<\mathrm{t}<45^{\circ} \mathrm{C}$ & 0,56 & 0,71 \\
\hline $45^{\circ} \mathrm{C}<\mathrm{t}<50^{\circ} \mathrm{C}$ & & \\
\hline
\end{tabular}

Tabel 3. Faktor Koreksi untuk KHA terus menerus untuk pemasangan tata letak kabel [ PUIL 2000 hal. 322-323 ]

\begin{tabular}{|c|c|c|c|c|c|c|}
\hline \multirow{2}{*}{$\begin{array}{l}\text { Penyusunan } \\
\text { kabel }\end{array}$} & \multirow{2}{*}{$\begin{array}{l}\text { Pe } \\
\text { ny } \\
\text { an } \\
\text { gg } \\
\text { a }\end{array}$} & \multicolumn{5}{|c|}{$\begin{array}{c}\text { Pemasangan berhimpit } \\
\text { Jumlah ikatan kabel }\end{array}$} \\
\hline & & 1 & 2 & 3 & 6 & 9 \\
\hline 1 & 2 & 9 & 10 & 11 & 12 & 13 \\
\hline $\begin{array}{l}\text { Kabel diatas } \\
\text { lantai }\end{array}$ & & 0,90 & 0,84 & 0.80 & 0,75 & 0,73 \\
\hline \multirow{4}{*}{$\begin{array}{l}\text { Kabel disusun } \\
\text { pada penyangga } \\
\text { tertutup }\end{array}$} & 1 & 0,95 & 0,84 & 0,80 & 0,75 & 0,73 \\
\hline & 2 & 0,95 & 0,80 & 0,76 & 0,71 & 0,69 \\
\hline & 3 & 0,95 & 0,78 & 0,74 & 0,70 & 0,68 \\
\hline & 6 & 0,95 & 0,76 & 0,72 & 0,86 & 0,66 \\
\hline \multirow{4}{*}{$\begin{array}{l}\text { Kabel disusun } \\
\text { pada penyangga } \\
\text { kabel terbuka }\end{array}$} & 1 & 0,95 & 0,84 & 0,80 & 0,75 & 0,73 \\
\hline & 2 & 0,95 & 0,80 & 0,76 & 0,71 & 0,69 \\
\hline & 3 & 0,95 & 0,78 & 0,74 & 0,70 & 0,68 \\
\hline & 6 & 0,95 & 0,76 & 0,72 & 0,68 & 0,68 \\
\hline $\begin{array}{l}\text { Kabel dipasang } \\
\text { satu diatas yang } \\
\text { lain pada rangka } \\
\text { besi atau } \\
\text { dinding }\end{array}$ & & 0,95 & 0,76 & 0,73 & 0,68 & 0,66 \\
\hline
\end{tabular}

\section{Metode Penelitian}

Pada penelitian ini menggunakan dua metode yaitu :

a. Perhitungan menggunakan rumus

b. Perhitungan menggunakan software Ecodial Advance Calculation INT 4.7.

Dari hasil perhitungan kemudian dibandingkan dengan unit terpasang. Hasil perbandingan dapat diketahui apakah unit terpasang sudah sesuai dengan standar PUIL 2000.

Pengumpulan data dilakukan dengan cara sebagai berikut :

a. Mengumpulkan data instalasi listrik dan wiring diagram gedung MCE Rumah Sakit Islam Sultan Agung Semarang.

b. Mendata panel MDP dan panel SDP yang berada di setiap lantai gedung. Mendata panel meliputi :

- MCB pada panel MDP dan panel SDP.

- Kabel penghantar pada panel MDP dan panel SDP.

- Beban daya listrik pada panel MDP dan panel SDP. c. Pengamatan lapangan langsung dan penjelasan oleh teknisi listrik gedung MCE RSI Agung Semarang.

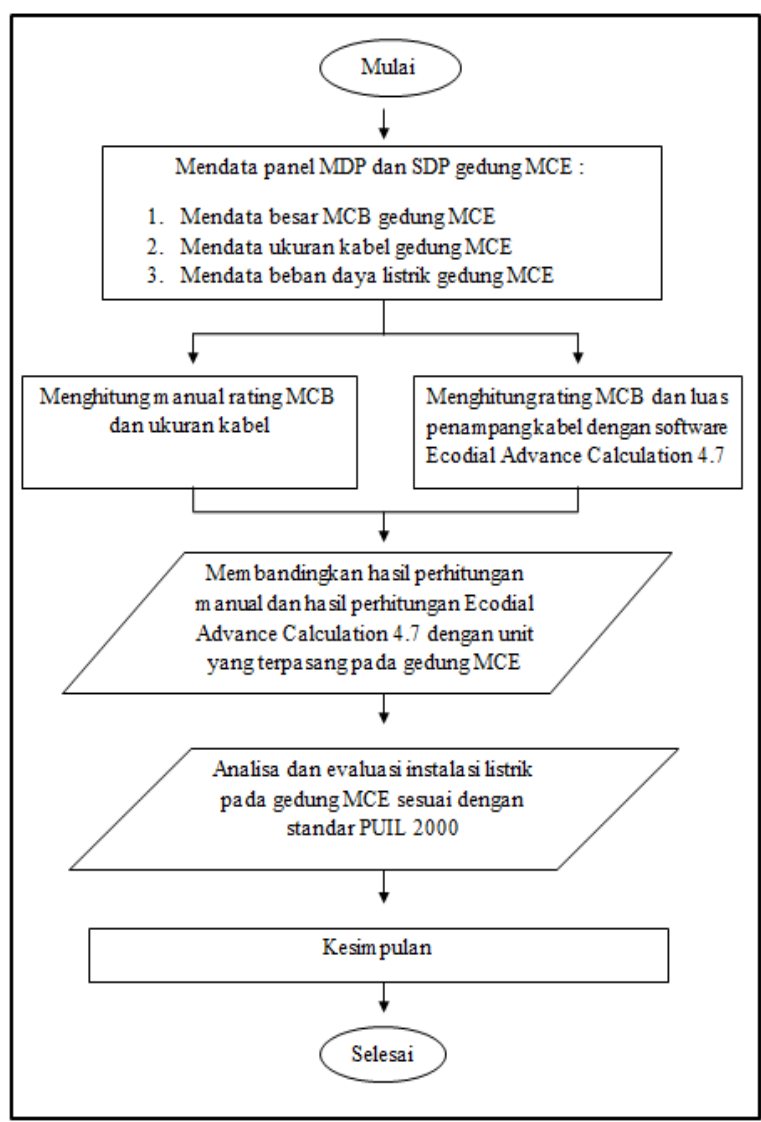

Gambar 1. Diagram alir evaluasi instalasi listrik gedung MCE.

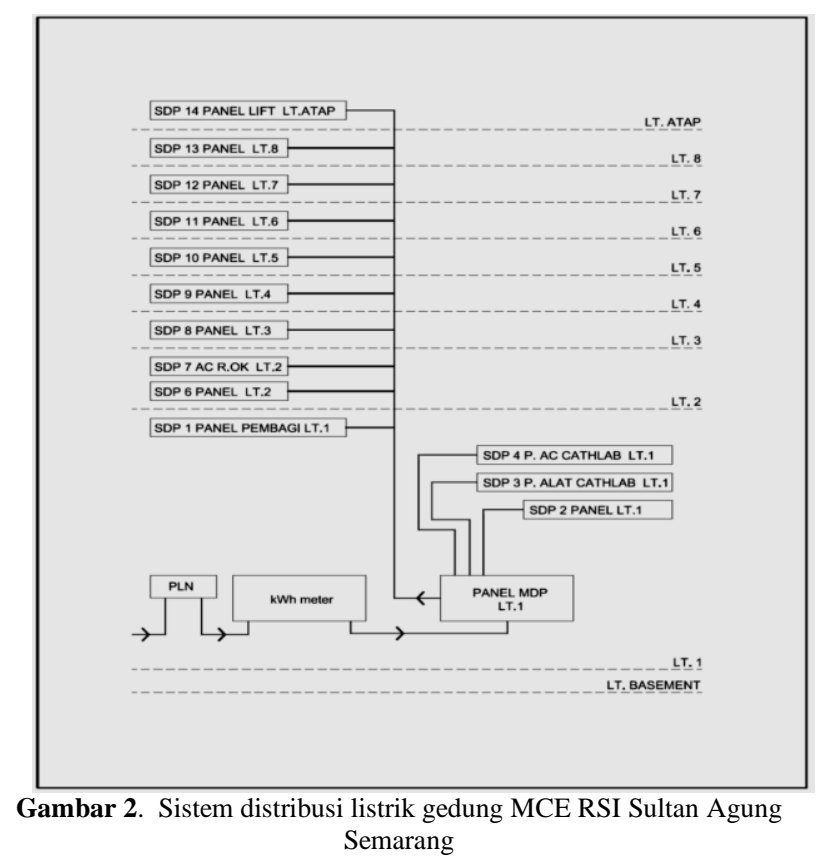

Tabel 4. Panel MDP Gedung MCE RSI Sultan Agung Semarang 


\begin{tabular}{|l|c|c|c|r|}
\hline \multicolumn{1}{|c|}{ NAMA BEBAN } & $\begin{array}{c}\text { MCB } \\
(\mathrm{A})\end{array}$ & $\begin{array}{c}\text { Isc } \\
(\mathrm{kA})\end{array}$ & $\begin{array}{c}\text { KABEL } \\
\left(\mathrm{mm}^{2}\right)\end{array}$ & $\begin{array}{c}\text { DAYA } \\
(\mathrm{W})\end{array}$ \\
\hline SDP 1 PANEL PEMBAGILT 1 & 200 & 25 & $4 \times 35$ & 88,285 \\
\hline SDP 2 PANEL LT 2 & 250 & 25 & $4 \times 70$ & 132,387 \\
\hline SDP 3 P. ALATCATHLABLT 1 & 250 & 25 & $4 \times 95$ & 100,000 \\
\hline SDP 4 P. AC CATHLAB LT 1 & 160 & 18 & $4 \times 25$ & 52,400 \\
\hline SDP 5 PANEL LT 2 & 250 & 25 & $4 \times 70$ & 109,620 \\
\hline SDP 6 PANEL AC R. OK LT 2 & 160 & 18 & $4 \times 25$ & 62,400 \\
\hline SDP 7 PANEL LT 3 & 160 & 18 & $4 \times 35$ & 67,346 \\
\hline SDP 8 PANELLT 4 & 160 & 18 & $4 \times 35$ & 74,101 \\
\hline SDP 9 PANEL LT 5 & 160 & 18 & $4 \times 50$ & 75,531 \\
\hline SDP 10 PANEL LT 6 & 200 & 25 & $4 \times 50$ & 81,051 \\
\hline SDP 11 PANEL LT 7 & 160 & 18 & $4 \times 35$ & 64,487 \\
\hline SDP 12 PANEL LT 8 & 160 & 18 & $4 \times 35$ & 58,429 \\
\hline SDP 13 PANEL LIFT LT ATAP & 160 & 18 & $4 \times 70$ & 22,000 \\
\hline PANEL MDP LT 1 & 2000 & 65 & $24 \times 300$ & 998,037 \\
\hline
\end{tabular}

\section{HASIL DAN ANALISA}

Untuk menentukan rating MCB yaitu dengan cara menghitung arus nominal yang mengalir pada beban. Besar rating MCB yang digunakan adalah lebih besar dari arus nominal dari hasil perhitungan.

Contoh perhitungan :

SDP 1 Panel Pembagi diketahui :

$$
\begin{gathered}
\mathrm{P} \quad=88.285 \text { watt } \\
\mathrm{VLL}=380 \text { volt } \\
\cos \theta=0,85 \\
\text { In }=\frac{P}{(\sqrt{3} \times V L L \times \cos \theta)} \\
\text { In }=\frac{88.285}{(\sqrt{3 \times 380 \times 0,85)}} \\
\text { In }=157,8 \mathrm{~A}
\end{gathered}
$$

Rating MCB yang digunakan $=160 \mathrm{~A}$

Cara menentukan ukuran kabel yaitu

KHA efiensi=KHA Kabelxfaktor koreksi

dimana, KHA efisien kabel > Arus nominal (In)

Arus nominal pada beban dikali asumsi pertumbuhan beban $20 \%$, kemudian dipilih KHA sesuai dengan PUIL 2000 pada tabel 7.3-5a, kemudian dikalikan dengan faktor koreksi sesuai PUIL 2000 tabel 7.3-2 dan 7.3-19. Faktor koreksi suhu dipilih 0,87 dengan asumsi kondisi lingkungan disekitar kabel memungkinkan terjadi peningkatan suhu hingga $40^{\circ} \mathrm{C}$ dan faktor koreksi pemasangan kabel dipilih 0,73 dengan melihat kondisi pemasangan kabel yaitu kabel dipasang berhimpitan pada dinding dengan jumlah ikatan 3 .

Contoh perhitungan :

Pada SDP 1 Panel Pembagi diketahui :

Arus nominal pada SDP 1 Panel Pembagi yaitu 157,8 A dikali pertumbuhan beban $20 \%$ yaitu 189,4 A, maka sesuai dengan tabel (2.5) dipilih luas penghantar minimal yaitu 95 $\mathrm{mm}^{2}$, kemudian dikalikan dengan faktor koreksi. Faktor koreksi suhu dipilih 0,87 dengan asumsi kondisi lingkungan di sekitar kabel memungkinkan terjadi peningkatan suhu hingga $40^{\circ} \mathrm{C}$. Faktor koreksi pemasangan kabel dipilih 0,73 dengan melihat kondisi pemasangan kabel yaitu kabel dipasang berhimpit pada dinding dengan jumlah ikatan 3 .

KHA efiensi $=$ KHA Kabelxfaktor koreksi

$$
\begin{aligned}
& =269 \times 0.87 \times 0.73 \\
& =210 \mathrm{~A}
\end{aligned}
$$

dimana,

KHA efisien kabel > Arus nominal (In)

Sehingga ukuran kabel yang digunakan ialah NYY $95 \mathrm{~mm}^{2}$.

Tabel 5. Standarisasi instalasi

\begin{tabular}{|c|c|}
\hline Standar instalasi & IEC60364 \\
\hline Standar perhitungan & TR50480 \\
\hline Standar pengaman & IEC 60947-2 \\
\hline Frekuensi & $50 \mathrm{~Hz}$ \\
\hline MaksimalkabelCSA & $300 \mathrm{~mm}^{2}$ \\
\hline
\end{tabular}

Tabel 6. Panel MDP Lantai 1

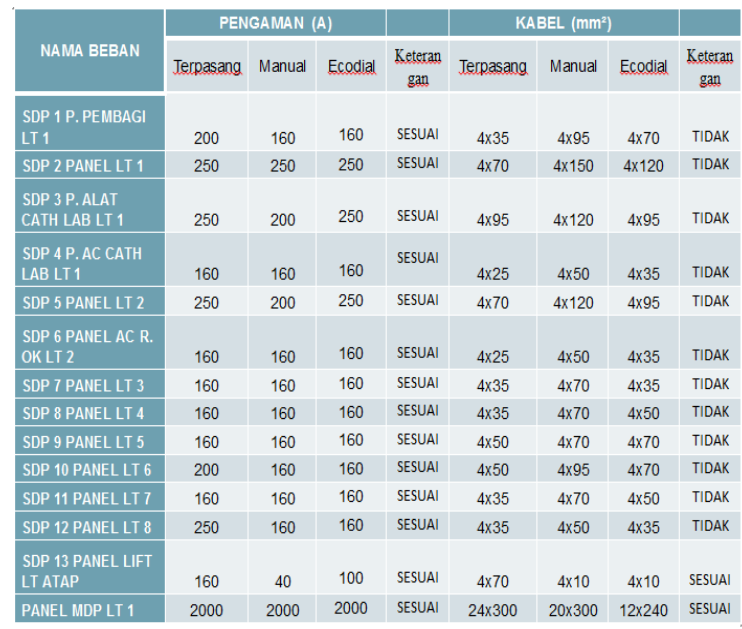

Tabel 7. SDP 1 Panel Pembagi Lt 1

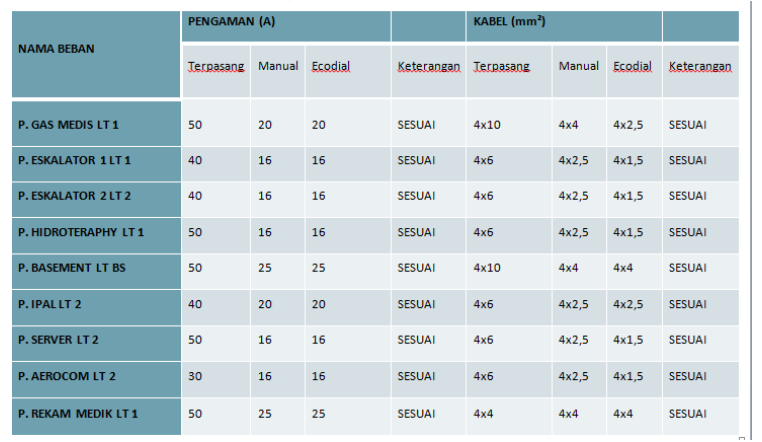

Tabel 8. SDP 2 Panel Lantai 1 


\begin{tabular}{|c|c|c|c|c|c|c|c|c|}
\hline \multirow{2}{*}{ NAMA BEBAN } & \multicolumn{3}{|c|}{ PENGAMAN (A) } & & \multicolumn{3}{|c|}{ KABEL $\left(m^{2}\right)^{2}$} & \multirow[b]{2}{*}{ Keterangan } \\
\hline & Terpasang & Manual & Ecodial & Keterangan & Terpasang & Manual & Ecodial & \\
\hline PP. 2 CATHLAB LT 1 & 25 & 16 & 13 & SESUAI & $4 \times 10$ & $4 \times 1,5$ & $4 \times 1,5$ & SESUAI \\
\hline PP. 4LT 1 & 160 & 160 & 160 & SESUAI & $4 \times 70$ & $4 \times 50$ & $4 \times 35$ & SESUAI \\
\hline P. AC 2 LT 1 & 100 & 100 & 100 & SESUAI & $4 \times 35$ & $4 \times 25$ & $4 \times 16$ & SESUAI \\
\hline P. AC 3 LT 1 & 100 & 63 & 63 & SESUAI & $4 \times 35$ & $4 \times 25$ & $4 \times 16$ & SESUAI \\
\hline
\end{tabular}

Tabel 9. SDP 3 Alat CathLab Lantai 1

\begin{tabular}{|c|c|c|c|c|c|c|c|c|}
\hline & Terpasang & Manual & Ecodial & Keterangan & Terpasang & Manual & Ecodial & Keterangan \\
\hline $\begin{array}{l}\text { SDP } 3 \text { P. ALAT } \\
\text { CATHLAB LT } 1\end{array}$ & 250 & 200 & 250 & SESUAI & $4 \times 95$ & $4 \times 120$ & $4 \times 95$ & TIDAK \\
\hline
\end{tabular}

Tabel 10.Pada SDP 4 P AC CathLab Lt 1

\begin{tabular}{|c|c|c|c|c|c|c|c|c|}
\hline \multirow{2}{*}{ NAMA BEBAN } & \multicolumn{3}{|c|}{ PENGAMAN (A) } & \multirow[b]{2}{*}{ Keterangan } & \multicolumn{3}{|c|}{ KABEL $\left(\mathrm{mm}^{2}\right)$} & \multirow[b]{2}{*}{ Keterangar } \\
\hline & Terpasang & Manual & Ecodial & & Terpasang & Manual & Ecodial & \\
\hline P. AC CATHLAB 1 LT 1 & 60 & 40 & 40 & SESUAI & $4 \times 16$ & $4 \times 10$ & $4 \times 10$ & SESUAI \\
\hline P. AC CATHLAB 2 LT 1 & 60 & 40 & 40 & SESUAI & $4 \times 16$ & $4 \times 10$ & $4 \times 10$ & SESUAI \\
\hline P. AC CATHLAB 3 LT 1 & 20 & 16 & 16 & SESUAI & $4 \times 16$ & $4 \times 1,5$ & $4 \times 1,5$ & SESUAI \\
\hline P. AC CATHLAB 4 LT 1 & 20 & 16 & 16 & SESUAI & $4 \times 16$ & $4 \times 1,5$ & $4 \times 1,5$ & SESUAI \\
\hline P. AC CATHLAB 5 LT 1 & 20 & 10 & 10 & SESUAI & $4 \times 16$ & $4 \times 1,5$ & $4 \times 1,5$ & SESUAI \\
\hline P. AC CATHLAB 6 LT 1 & 20 & 10 & 10 & SESUAI & $4 \times 16$ & $4 \times 1,5$ & $4 \times 1,5$ & SESUAI \\
\hline
\end{tabular}

Tabel 11.Pada SDP 5 Panel Lantai 2

\begin{tabular}{|c|c|c|c|c|c|c|c|c|}
\hline \multirow{2}{*}{ NAMA BEBAN } & \multicolumn{3}{|c|}{ PENGAMAN (A) } & & \multicolumn{3}{|c|}{$\operatorname{KABEL}\left(\mathrm{mm}^{2}\right)$} & \multirow[b]{2}{*}{ Keteranga } \\
\hline & Terpasang & Manual & Ecodial & Keterangan & Terpasang & Manual & Ecodial & \\
\hline PP. 5 R. PHECO LT 2 & 25 & 16 & 16 & SESUAI & $4 \times 6$ & $4 \times 2,5$ & $4 \times 1,5$ & SESUAI \\
\hline PP. 6R. OKLT2 & 25 & 6 & 6 & SESUAI & $4 \times 6$ & $4 \times 1,5$ & $4 \times 1,5$ & SESUAI \\
\hline PP.7LT2 & 100 & 100 & 100 & SESUAI & $4 \times 35$ & $4 \times 25$ & $4 \times 16$ & SESUAI \\
\hline P. AC5 LT 2 & 80 & 50 & 50 & SESUAI & $4 \times 25$ & $4 \times 16$ & $4 \times 10$ & SESUAI \\
\hline P. AC 6 LT 2 & 100 & 63 & 63 & SESUAI & $4 \times 35$ & $4 \times 25$ & $4 \times 16$ & SESUAI \\
\hline
\end{tabular}

Tabel 12.Pada SDP 6 P. AC R. OK Lantai 2

\begin{tabular}{|c|c|c|c|c|c|c|c|c|}
\hline \multirow{2}{*}{ NAMA BEBAN } & \multicolumn{3}{|c|}{ PENGAMAN (A) } & \multirow[b]{2}{*}{ Ketrerangan } & \multicolumn{3}{|c|}{ KABEL $\left(\mathrm{mm}^{2}\right)$} & \multirow[b]{2}{*}{ Keterangan } \\
\hline & Terpasang & Manual & Ecodial & & Terpasang & Manual & Ecodial & \\
\hline P. ACR. OK1 LT2 2 & 60 & 40 & 40 & SESUAI & $4 \times 16$ & $4 \times 10$ & $4 \times 10$ & SESUAI \\
\hline P. ACR. OK 2 LT 2 & 60 & 40 & 40 & SESUAI & $4 \times 16$ & $4 \times 10$ & $4 \times 10$ & SESUAI \\
\hline P. ACR. OK 3 LT 2 & 20 & 16 & 16 & SESUAI & $4 \times 16$ & $4 \times 1,5$ & $4 \times 1,5$ & SESUAI \\
\hline P. ACR. OK 4 LT 2 & 20 & 16 & 16 & SESUAI & $4 \times 16$ & $4 \times 1,5$ & $4 \times 1,5$ & SESUAI \\
\hline P. ACR. OK 5 LT 2 & 20 & 10 & 10 & SESUAI & $4 \times 16$ & $4 \times 1,5$ & $4 \times 1,5$ & SESUAI \\
\hline P. ACR. OK 6 LT 2 & 20 & 10 & 10 & SESUAI & $4 \times 16$ & $4 \times 1,5$ & $4 \times 1,5$ & SESUAI \\
\hline
\end{tabular}

Tabel 13..SDP 7 Panel Lantai 3

\begin{tabular}{|c|c|c|c|c|c|c|c|c|}
\hline \multirow{2}{*}{ NAMA BEBAN } & \multicolumn{3}{|c|}{ PENGAMAN (A) } & \multirow[b]{2}{*}{ Keterangan } & \multicolumn{3}{|c|}{$\operatorname{KABE}\left(\mathrm{mm}^{2}\right)$} & \multirow[b]{2}{*}{ Keterangan } \\
\hline & Terpasang & Manual & Ecodial & & Terpasang & Manual & Ecodial & \\
\hline PP. 8 LT 3 & 100 & 100 & 100 & SESUAI & $4 \times 35$ & $4 \times 25$ & $4 \times 16$ & SESUAI \\
\hline P. AC 8 LT 3 & 100 & 63 & 63 & SESUAI & $4 \times 35$ & $4 \times 16$ & $4 \times 16$ & SESUAI \\
\hline
\end{tabular}

Tabel 14.Panel SDP 8 Panel Lantai 4

\begin{tabular}{|c|c|c|c|c|c|c|c|c|}
\hline \multirow{2}{*}{ NAMA BEBAN } & \multicolumn{3}{|c|}{ PENGAMAN (A) } & \multirow[b]{2}{*}{ Keterangan } & \multicolumn{3}{|c|}{ KABEL $\left(\mathrm{mm}^{2}\right)$} & \multirow[b]{2}{*}{ Keterangan } \\
\hline & Terpasang & Manual & Ecodial & & Terpasang & Manual & Ecodial & \\
\hline PP. 9 LT 4 & 100 & 100 & 100 & SESUAI & $4 \times 35$ & $4 \times 25$ & $4 \times 16$ & SESUAI \\
\hline P. AC9LT 4 & 100 & 100 & 100 & SESUAI & $4 \times 35$ & $4 \times 25$ & $4 \times 16$ & SESUAI \\
\hline
\end{tabular}

Tabel 15..Panel SDP 9 Panel Lantai 5

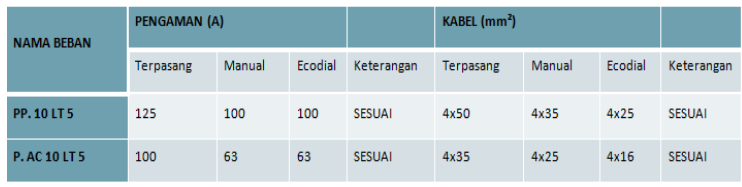

Tabel 16.Panel SDP 10 Panel Lantai 6

\begin{tabular}{|l|l|l|l|l|l|l|l|l|}
\hline \multirow{2}{*}{ NAMA BEBAN } & \multicolumn{2}{|l|}{ PENGAMAN (A) } & & \multicolumn{5}{l|}{ KABEL $\left(\mathrm{mm}^{2}\right)$} \\
& Terpasang & Manual & Ecodial & Keterangan & Terpasang & Manual & Ecodial & Keterangan \\
\hline PP.11 LT6 & 125 & 100 & 100 & SESUAl & $4 \times 50$ & $4 \times 35$ & $4 \times 35$ & SESUAl \\
\hline P. AC 11 LT6 & 100 & 63 & 63 & SESUAI & $4 \times 35$ & $4 \times 16$ & $4 \times 16$ & SESUAI \\
\hline
\end{tabular}

Tabel 17.Panel SDP 11 Panel Lantai 7

\begin{tabular}{|c|c|c|c|c|c|c|c|c|}
\hline \multirow{2}{*}{ NAMA BEBAN } & \multicolumn{3}{|c|}{ PENGAMAN (A) } & & \multicolumn{3}{|c|}{ KABEL $\left(\mathrm{mm}^{2}\right)$} & \multirow[b]{2}{*}{ Keterangan } \\
\hline & Terpasang & Manual & Ecodial & Keterangan & Terpasang & Manual & Ecodial & \\
\hline PP. 12 LT 7 & 100 & 100 & 100 & SESUAI & $4 \times 35$ & $4 \times 25$ & $4 \times 25$ & SESUAI \\
\hline P. AC 12 LT7 & 60 & 50 & 50 & SESUAI & $4 \times 16$ & $4 \times 16$ & $4 \times 10$ & SESUAI \\
\hline
\end{tabular}

Tabel 18.Panel SDP 12 Panel Lantai 8

\begin{tabular}{|c|c|c|c|c|c|c|c|c|}
\hline \multirow{2}{*}{ NAMA BEBAN } & \multicolumn{3}{|c|}{ PENGAMAN (A) } & \multirow[b]{2}{*}{ Keterangan } & \multicolumn{3}{|c|}{ KABEL $\left(\mathrm{mm}^{2}\right)$} & \multirow[b]{2}{*}{ Keterangan } \\
\hline & Terpasang & Manual & Ecodial & & Terpasang & Manual & Ecodial & \\
\hline PP. 13 LT 8 & 100 & 63 & 63 & SESUAI & $4 \times 35$ & $4 \times 25$ & $4 \times 16$ & SESUAI \\
\hline P. AC 13 LT 8 & 60 & 50 & 50 & SESUAI & $4 \times 25$ & $4 \times 16$ & $4 \times 10$ & SESUAI \\
\hline
\end{tabular}

Tabel 19.Panel SDP 13 Panel Lift Lt. Atap

\begin{tabular}{|c|c|c|c|c|c|c|c|c|}
\hline \multirow{2}{*}{ NAMA BEBAN } & \multicolumn{3}{|c|}{ PENGAMAN (A) } & & \multicolumn{3}{|c|}{ KABEL $\left(\mathrm{mm}^{2}\right)$} & \multirow[b]{2}{*}{ Keterangan } \\
\hline & Terpasang & Manual & Ecodial & Keterangan & Terpasang & Manual & Ecodial & \\
\hline P. LIFT 1 LT ATAP & 80 & 20 & 20 & SESUAI & $4 \times 35$ & $4 \times 4$ & $4 \times 2,5$ & SESUAI \\
\hline P. LIF 2 LT ATAP & 80 & 20 & 20 & SESUAI & $4 \times 25$ & $4 \times 4$ & $4 \times 2,5$ & SESUAI \\
\hline
\end{tabular}

Dari hasil perbandingan antara unit repasang dengan hasil perhitungan manual dan perhitungan ecodial ada beberapa ukuran kabel dalam kondisi tidak sesuai dengan standar PUIL 2000 dan sesuai perhitungan, yaitu :

a) Kabel SDP 1 PANEL PEMBAGI LT 1 sebesar $4 \times 35 \mathrm{~mm}^{2}$ menjadi $4 \times 95 \mathrm{~mm}^{2}$.

b) Kabel SDP 2 PANEL LT 1 sebesar $4 \times 70 \mathrm{~mm}^{2}$ menjadi $4 \times 150 \mathrm{~mm}^{2}$.

c) Kabel SDP 3 PANEL ALAT CATH LAB LT 1 sebesar 4x95 mm2 menjadi 4x120 mm2.

d) Kabel SDP 4 PANEL AC CATH LAB LT 1 sebesar 4x25 $\mathrm{mm} 2$ menjadi $4 \times 50 \mathrm{~mm} 2$.

e) Kabel SDP 5 PANEL LT 2 sebesar $4 \times 70 \mathrm{~mm} 2$ menjadi $4 \times 120 \mathrm{~mm} 2$.

f) Kabel SDP 6 PANEL AC R. OK LT 2 sebesar $4 \times 25$ mm2 menjadi $4 \times 50 \mathrm{~mm} 2$.

g) Kabel SDP 7 PANEL LT 3 sebesar $4 \times 35$ mm2 menjadi $4 \times 70 \mathrm{~mm} 2$.

h) Kabel SDP 8 PANEL LT 4 sebesar $4 \times 35 \mathrm{~mm} 2$ menjadi $4 \times 70 \mathrm{~mm} 2$.

i) Kabel SDP 9 PANEL LT 5 sebesar $4 \times 50 \mathrm{~mm} 2$ menjadi $4 \times 70 \mathrm{~mm} 2$.

j) Kabel SDP 10 PANEL LT 6 sebesar 4x50 mm2 menjadi $4 \times 95 \mathrm{~mm} 2$.

k) Kabel SDP 11 PANEL LT 7 sebesar 4x35 mm2 menjadi $4 \times 70 \mathrm{~mm} 2$. 
1) Kabel SDP 12 PANEL LT 8 sebesar $4 \times 35 \mathrm{~mm} 2$ menjadi $4 \times 50 \mathrm{~mm} 2$.

\section{KESIMPULAN}

1. Pengaman MCB yang digunakan pada instalasi gedung MCE RSI Sultan Agung Semarang dalam kondisi aman sesuai dengan standar PUIL 2000.

2. Ukuran kabel yang digunakan pada instalasi gedung MCE RSI Sultan Agung Semarang beberapa dalam kondisi tidak sesuai dengan standar PUIL 2000. Hal ini terjadi karena pada perhitungan unit terpasang tidak memperhitungkan pertumbuhan beban dan faktor koreksi sesuai dengan standar PUIL 2000.

3. Perbedaan hasil perhitungan ukuran kabel antara perhitungan manual dengan perhitungan menggunakan software Ecodial Advance Calculation 7.4 karena pada perhitungan manual memperhitungkan pertumbuhan beban sebesar $20 \%$.

\section{DAFTAR PUSTAKA}

Merlin Gerin, Arus Hubung Pendek,PT. Schneider Ometraco, 1997.

Persyaratan Umum Instalasi Listrik 2000. Jakarta : Badan Standarisasi Nasional PUIL 2000

Setiawan E, P.Van Harten, Instalasi Listrik Arus Kuat 1, Jakarta: Binacipta, 1986

Setiawan E, P.Van Harten, Instalasi Listrik Arus Kuat 3, Jakarta: Binacipta, 1989

Suhardi, Bambang, dkk, Teknik Distribusi Tenaga Listrik Jilid 1, Jakarta : Direktorat Pembinaan Sekolah Menengah Kejuruan, 2008

http://www.schneider-electric.com 